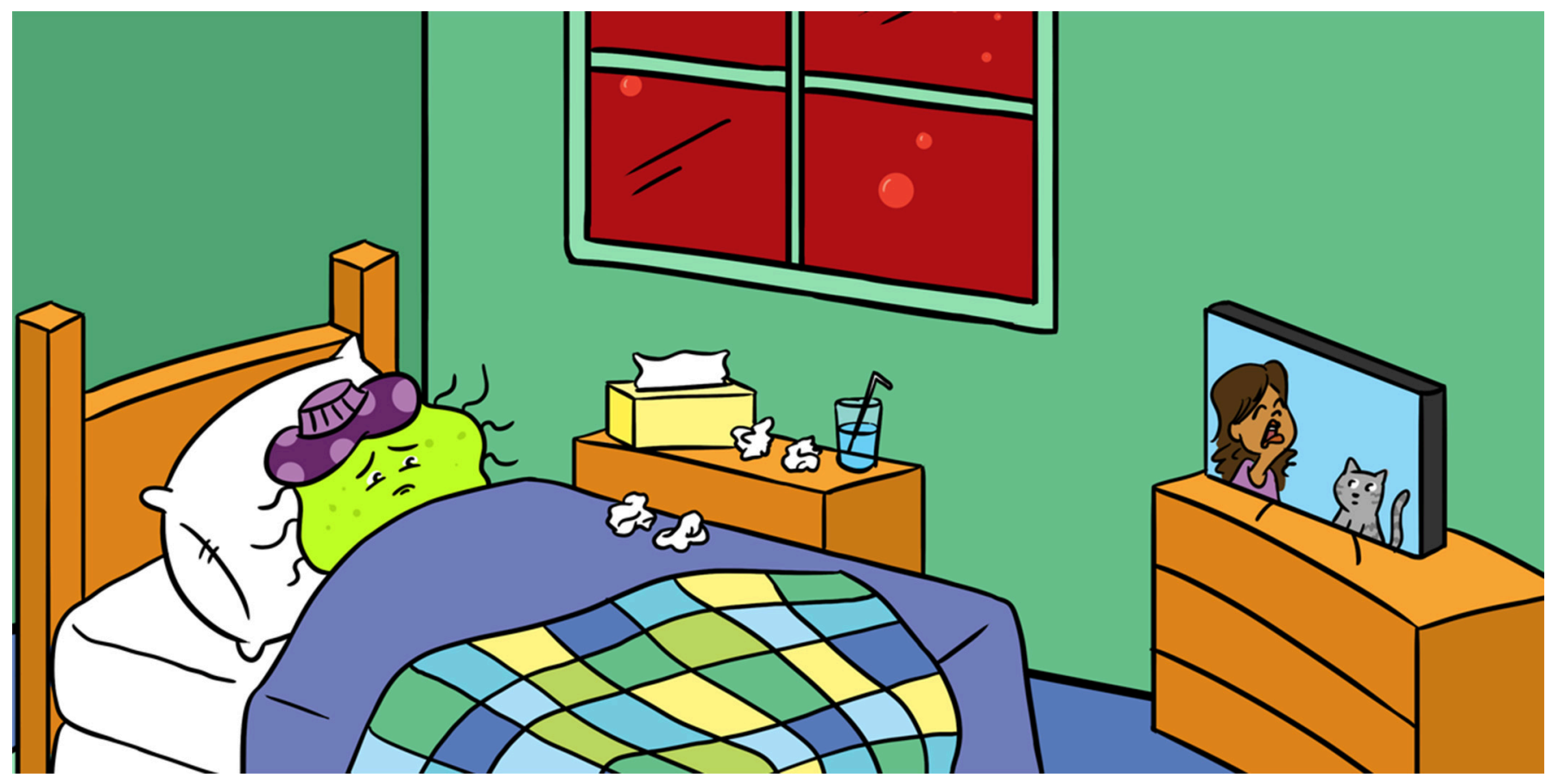

\title{
WHAT BACTERIA DO WHEN THEY GET SICK
}

\section{JL Weissman ", Hao H. Yiu and Philip L. F. Johnson}

Department of Biology, University of Maryland, College Park, MD, United States

YOUNG REVIEWERS:

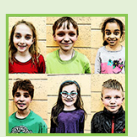

FRIESS

LAKE

ELEMENTARY

AGES: 8-9
Bacteria are really small, so small you cannot even see them. Did you know that bacteria can still get sick, just like us? In fact, most viruses in the world infect bacteria, not people. What happens when a bacterium gets infected by a virus? Well, just like us, many bacteria have their own immune systems that help defend against infections. Recently, scientists have discovered some new bacterial immune systems. We have been able to re-purpose these systems for entirely new uses. One such immune system, called CRISPR, can potentially allow us to rewrite DNA any way we want, in any living thing. Now scientists are using bacterial immune systems as powerful tools to precisely edit the DNA of all sorts of living things.

\section{VIRUSES INFECT BACTERIA}

Did you know that bacteria can get sick, just like you? If you have ever caught a cold or had the flu you know it is no fun getting infected with a virus. Well, it turns out that most of the viruses in the world infect bacteria instead of people. Scientists call these viruses bacteriophages (which literally means "bacteria eaters"). There are around $10^{30}$ viruses 


\section{VIRUS}

A virus is a small amount of DNA or RNA surrounded by a protein shell. Basically, a virus is just an instruction manual for building more viruses When the virus enters a living cell (a human cell, if the virus infects humans, or a bacterial cell, if the virus infects bacteria) it reprograms that cell and turns the cell into a virus factory.

\section{ADAPTIVE}

\section{IMMUNITY}

All organisms have different types of immunity to protect themselves against infection. Adaptive immune systems allow organisms to remember infections from the past in order to better fight against those same infections in the future.

\section{BACTERIUM}

A bacterium is a microscopic organism made up of a single cell. Their cells are much simpler than a human's, too. Some bacteria can make you sick, but most do not. In fact, you rely on the bacteria in your gut to stay healthy! in the ocean (that is a one with 30 zeroes behind it!). That is more viruses than there are stars in the universe! Most of these ocean viruses infect bacteria [1].

Maybe all of this is new to you, but bacteria and viruses have been around for a very long time. Bacteria have been evolving alongside viruses since the origin of life. They have been locked in a constant battle for over 3 billion years [2]. After all that time, bacteria have evolved a few tricks to defend themselves.

\section{BACTERIA DEFEND THEMSELVES, JUST LIKE WE DO}

Your body has lots of ways to keep you from getting sick or to help you get better more quickly when you do get sick. Your first line of defense is your skin and the membranes inside your body. These keep nasty bacteria and viruses away just like a wall. When you get a cut, why do you have to be careful to keep it clean? So that you do not get an infection.

Sometimes though, your skin is not enough, and you do get sick. When you get a fever, that is a sign that your body is trying to fight whatever is causing you to be sick. There are some clever ways your body can fight infection [3]. After your body fights off an infection by a virus for the first time, it can form a memory of what that virus looks like. That way, you would not get sick from that virus again. You will recognize the "bad guy" and fight back. We call this memory "adaptive immunity," and it is why people usually only get the chicken pox once, and it is also why vaccines work. A vaccine shows your body a little bit of a dead or weakened virus, so your body can remember the virus and fight against the alive version later on. Some viruses change over time though, so that these memories do not work forever. Have you gotten a cold or the flu more than once? That is because these viruses change quickly. Each time you get sick, it is actually a slightly different version of the cold or flu.

Bacteria seem a lot simpler than us. After all, they are really tiny and only made up of a single cell. Bacteria do not have brains or other organs. Even their one cell looks much simpler than one of our own cells. Even so, bacteria can defend themselves from viruses a lot like we do.

First of all, each bacterium is surrounded by a "cell membrane" and a "cell wall." These structures are like shields that protect bacteria from the world, similar to the way your skin protects you. Viruses need to attach to the outside of a cell and poke through to get inside. If the bacteria change the shape of their cell walls, this can prevent viruses from sticking to them. Then the bacteria are protected from infection. 


\section{CRISPR}

CRISPR is an adaptive immune system that bacteria use to fight off viral infections. CRISPR allows bacteria to remember viruses they have seen in the past, and recognize and fight these viruses in the future.
What happens if a virus does get through a bacterium's cell wall? Well, some bacteria also have adaptive immunity, just like we do! That means they can store a memory of a virus to help them protect themselves later on. Scientists only discovered this relatively recently $[4,5]$. Before, nobody thought bacteria were complex enough to have something like adaptive immunity. Nature continues to surprise scientists with new, weird stuff. We call the system that provides adaptive immunity in bacteria the "CRISPR" system.

CRISPR stands for "clustered regularly-interspaced short palindromic repeats," which is a complicated way of describing what CRISPR looks like. When scientists sequenced the genetic code of some bacteria (their DNA), they found a pattern in which the same short sequence was repeated over and over again with some gaps in-between (regularly-interspaced). These short repeated bits were palindromes, meaning they looked the same going forward or backward (like the words "kayak" and "racecar"). Finally, all of the repeats were found clustered close to each other in the bacterial DNA. Hence, the scientists came up with the name CRISPR. We admit that the name is pretty confusing, but I would not worry about it if I were you. Scientists do an OK job at figuring out how the world works, but we are not great at coming up with simple names for things.

\section{HOW DOES CRISPR WORK?}

What do we mean when we say that CRISPR helps bacteria "remember" a virus? Well, to understand that, first you have to understand what a virus is. Unlike humans, and unlike bacteria, viruses are not made of cells. Instead, a virus is a bunch of DNA or RNA (a molecule related to DNA) packaged tightly into a capsule made of proteins. You can think of DNA as a long book describing what a living thing is supposed to be like. For example, your DNA describes how your body should work, and this "code," along with the world around you, shapes how you grow. All living things store their genetic code as DNA, but some viruses have RNA instead. RNA does pretty much the same thing as DNA for viruses but is built a little differently (think of the code for those viruses being written on stone tablets instead of paper).

At the beginning of an infection, the virus' DNA or RNA gets injected into a cell (a human cell, if the virus infects humans, or a bacterial, cell if the virus infects bacteria). Afterward, the virus reprograms the cell to make lots of copies of the virus. Eventually, these copies are packaged into new capsules. Finally, the cell is broken open and lots of newborn viruses go off into the world to infect new cells. You can see how this works in Figure 1.

CRISPR in bacterial cells works in two steps. First, when a bacterium has a CRISPR system, it can store little pieces of viral DNA. Each one 


\section{Figure 1}

How a virus infects a bacterium.

\section{DNA EDITING}

Scientists have figured out how to use CRISPR to edit DNA. That means they can potentially re-write the "instruction manual" that tells each organism how to live and grow. We call this "DNA editing."

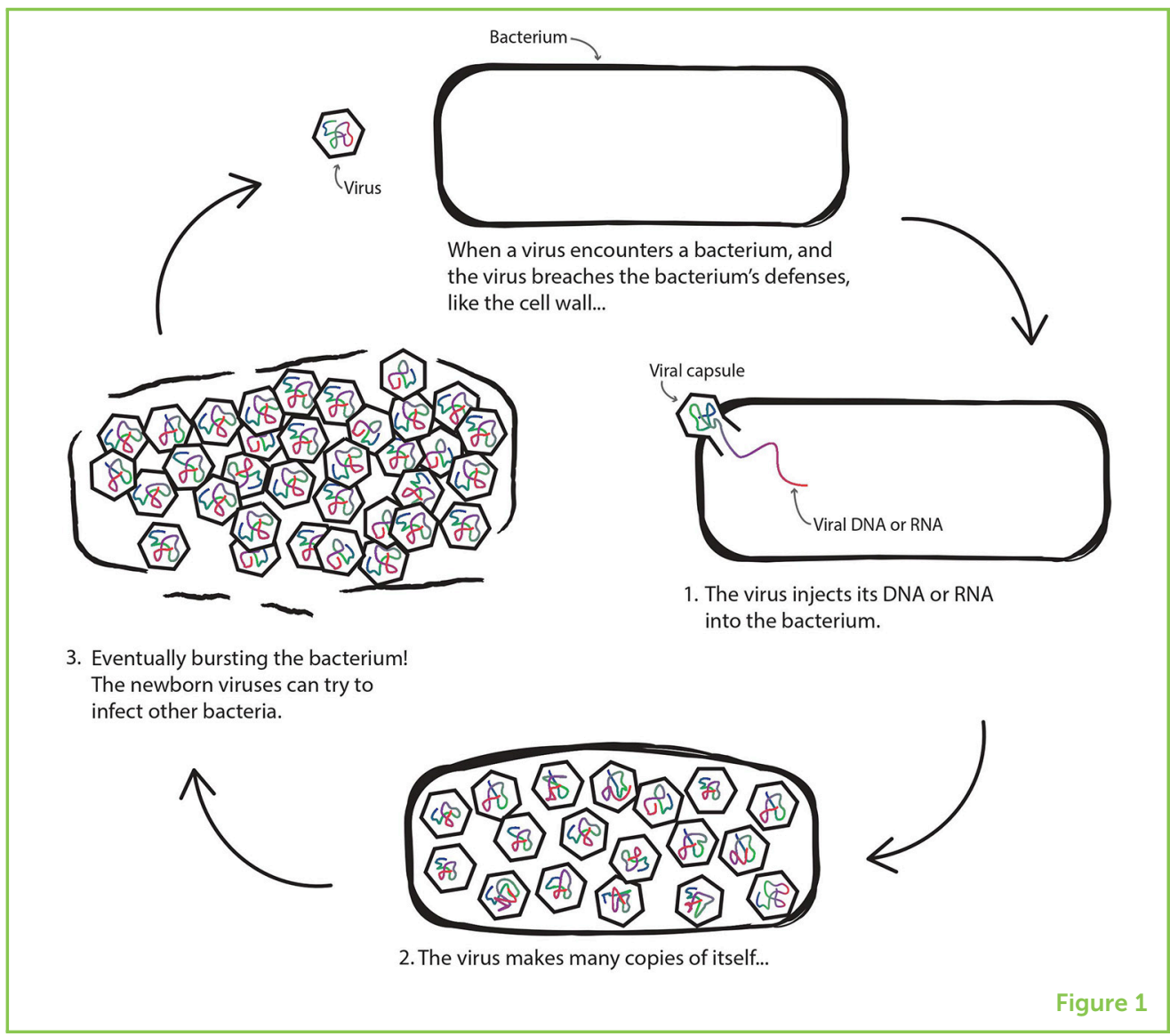

of these pieces can be thought of as a different "memory." Now the bacterium knows part of the virus' "code" and can recognize it as a "bad guy" later on. If a virus injects itself into a cell, and that virus matches one of the bacterium's stored memories, then the bacterium knows that there is something wrong. Once the bacterium knows that it is being infected, it starts the second step of CRISPR immunity. The bacterium uses its CRISPR system to chop up the virus before the virus has a chance to make copies of itself. Voila, no infection! We show how this works in Figure 2. Of course, bacteria do not "think" or "know" things like we do, because they do not have brains. All of the steps in CRISPR immunity happen automatically, but it is helpful to think of them as "memory" when trying to understand how they work.

\section{WHY DO WE CARE SO MUCH ABOUT CRISPR?}

Recently, CRISPR has been in the news a lot. People are very excited about this odd little system that bacteria use to fight viruses! Why so much excitement you ask? Well, it turns out that we humans are pretty good at stealing the tools bacteria have evolved over billions of years and using them for our own purposes. Scientists have been able to turn CRISPR into a way of "DNA editing" [6, 7]. Bacteria use CRISPR to cut the DNA of viruses in a very specific way. Scientists have figured 


\section{Figure 2}

How CRISPR defends a bacterium against viruses.

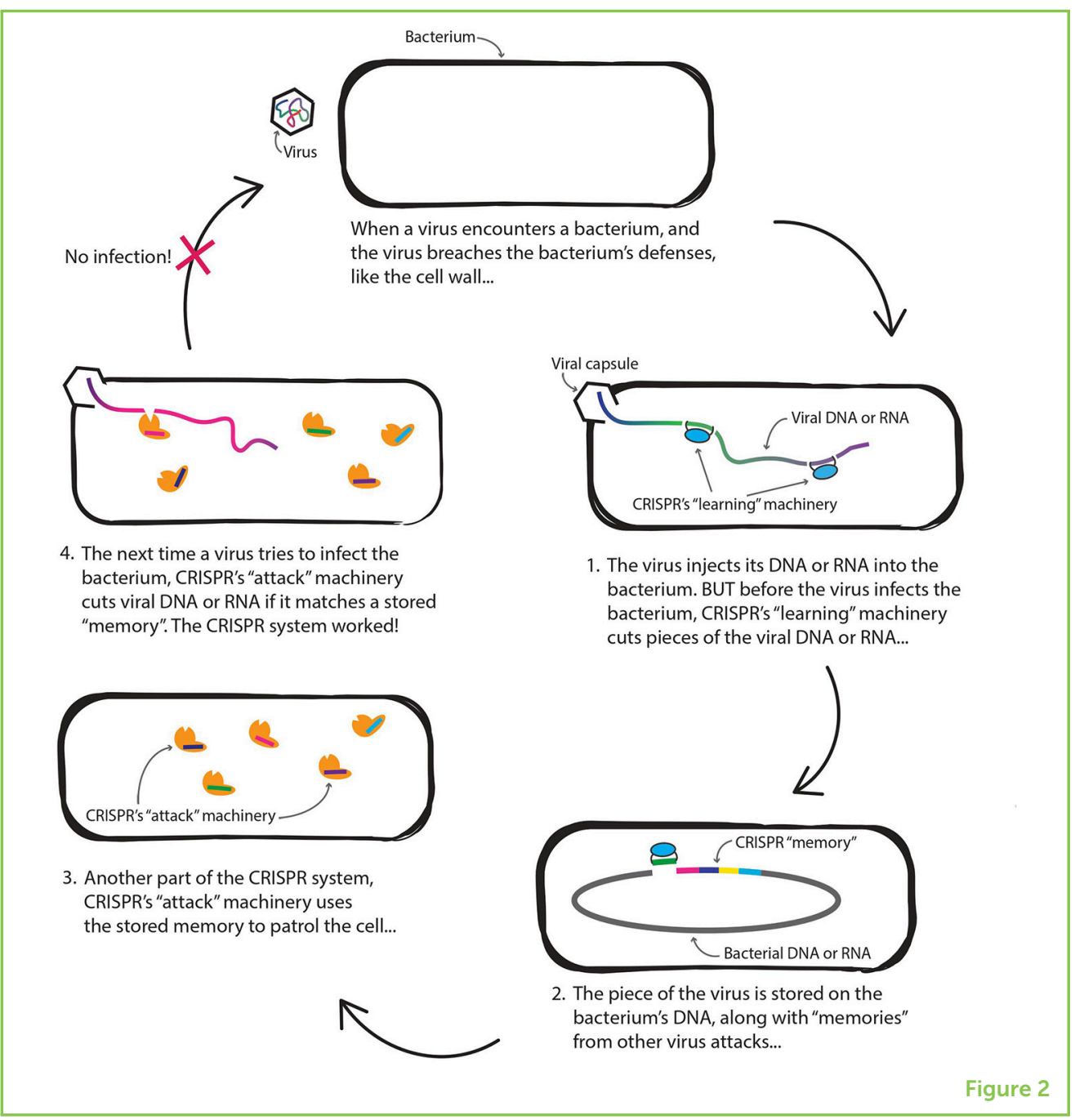

out how to use CRISPR to cut any DNA very precisely in any way we want!

Why do scientists want to edit DNA anyway? Some human diseases are very difficult to cure because they are coded into our DNA. These diseases are not caused by viruses or by bacteria. Some examples are sickle cell anemia and cystic fibrosis. These diseases are caused by tiny changes to the genetic code. These changes make the body work slightly differently from the way it otherwise would. With CRISPR, we can edit DNA, and maybe fix these small changes. This means that CRISPR could be used to help cure some of these genetic diseases. That is not all though. Scientists are using CRISPR to design hardier crops for us to eat, to try to get rid of disease-carrying mosquitoes, and much more.

We are still learning how to best use CRISPR as a tool. It is important that we make sure to use CRISPR for good reasons. Recently, a scientist reported that he had used CRISPR to edit the DNA of two children. He was trying to make them resistant to certain diseases. The global 
scientific community was very concerned when they learned this. Many scientists were worried about the scientific procedures used. Others doubted whether the researcher had acted ethically. Many scientists thought that the benefit did not outweigh the risks. The diseases that the edits would have prevented are easily preventable with other methods. CRISPR technology is not perfect yet, and could be harmful. Often, CRISPR can introduce changes into DNA where we do not want it to. Using the technology on humans can be risky. It is important to remember that, just because a scientist can do something, does not mean they should. Scientists around the world frequently hold big meetings to discuss these issues and the best way forward. At those meetings, they ask each other, and members of the public, questions like, "Is it ever OK to edit a human's DNA?" and "If so, when would it be OK?" What do you think? What if we use CRISPR to cure diseases? What if we use it for other purposes, like to make smarter or stronger people? What if only some families can afford it? It is important that we ask each other these questions and that we include concerned individuals from all over the globe. That way we can choose a path that better takes into account the needs and worries of everyone involved.

\section{REFERENCES}

1. Suttle, C. A. 2005. Viruses in the sea. Nature 437:356. doi: 10.1038/nature04160

2. Forterre, P. 2006. The origin of viruses and their possible roles in major evolutionary transitions. Virus Res. 117:5-16. doi: 10.1016/j.virusres.2006.01.010

3. Chaplin, D. D. 2010. Overview of the immune response. J. Allergy Clin. Immunol. 125:S3-23. doi: 10.1016/j.jaci.2009.12.980

4. Mojica, F. J., Díez-Villaseñor, C., García-Martínez, J., and Soria, E. 2005. Intervening sequences of regularly spaced prokaryotic repeats derive from foreign genetic elements. J. Mol. Evol. 60:174-82. doi: 10.1007/s00239-004-0046-3

5. Barrangou, R., Fremaux, C., Deveau, H., Richards, M., Boyaval, P., Moineau, S., et al. 2007. CRISPR provides acquired resistance against viruses in prokaryotes. Science 315:1709-12. doi: 10.1126/science.1138140

6. Jinek, M., Chylinski, K., Fonfara, I., Hauer, M., Doudna, J. A., and Charpentier, E. 2012. A programmable dual-RNA-guided DNA endonuclease in adaptive bacterial immunity. Science 337:816-21. doi: 10.1126/science.1225829

7. Gasiunas, G., Barrangou, R., Horvath, P., and Siksnys, V. 2012. Cas9-crRNA ribonucleoprotein complex mediates specific DNA cleavage for adaptive immunity in bacteria. Proc. Natl. Acad. Sci. U.S.A. 109:E2579-86. doi: 10.1073/pnas.1208507109

SUBMITTED: 11 February 2019; ACCEPTED: 09 July 2019; PUBLISHED ONLINE: 24 July 2019.

EDITED BY: Kari Merete Ersland, University of Bergen, Norway 

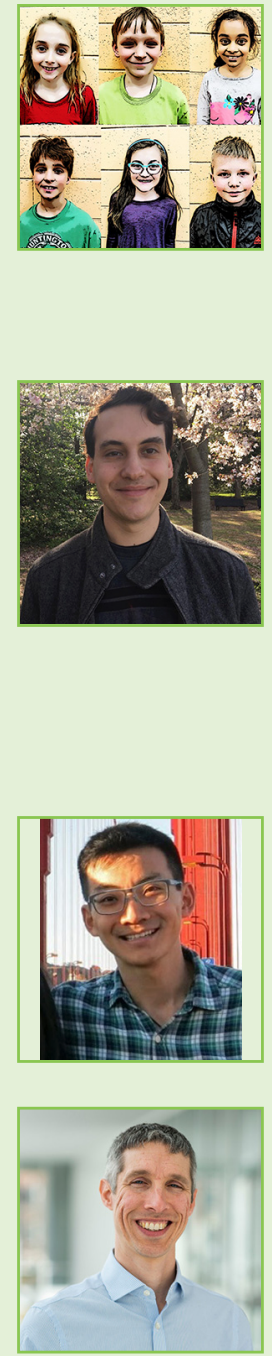

CITATION: Weissman J, Yiu HH and Johnson PLF (2019) What Bacteria Do When They Get Sick. Front. Young Minds 7:102. doi: 10.3389/frym.2019.00102

CONFLICT OF INTEREST STATEMENT: The authors declare that the research was conducted in the absence of any commercial or financial relationships that could be construed as a potential conflict of interest.

COPYRIGHT (c) 2019 Weissman, Yiu and Johnson. This is an open-access article distributed under the terms of the Creative Commons Attribution License (CC BY). The use, distribution or reproduction in other forums is permitted, provided the original author(s) and the copyright owner(s) are credited and that the original publication in this journal is cited, in accordance with accepted academic practice. No use, distribution or reproduction is permitted which does not comply with these terms.

\section{YOUNG REVIEWERS}

\section{FRIESS LAKE ELEMENTARY, AGES: 8-9}

This crazy group of students loves science and explosions. Oh yeah, and reading, too! It was not hard at all to convince them to stay after school to review the paper.

\section{AUTHORS}

\section{JL WEISSMAN}

They are a graduate student studying microbial ecology at the University of Maryland. They study how bacteria fight off viruses. Specifically, they want to know why different organisms have different types of immune systems. In order to figure that out, they use a lot of math and computer simulations. By building models about how we think living things behave, we can make predictions about how the world should work. Then we can go out into the world and test if our models are correct. *jw4336@terpmail.umd.edu

\section{HAO H. YIU}

Hao is a graduate student in the Biological Sciences at the University of Maryland. $\mathrm{He}$ is fascinated by the immune system in animals like us, from mice to birds to apes. He studies how the adaptive immune system uses evolution to do its job, and how evolution shaped the adaptive immune system over long periods of time.

\section{PHILIP L. F. JOHNSON}

Philip is now a Professor at the University of Maryland, but has been fascinated by genetics since his first biology course in ninth grade. However, it took many more years of school until he realized just how much genetics occurs literally under his nose (and everywhere else) thanks to microbes. Now he researches evolutionary genetics with a focus on immune systems and enjoys helping others get excited about microbes and evolution earlier in life than he did. 